УДК 376-056.36:37.013.77:005.336.2

DOI https://doi.org/10.32838/2709-3093/2021.2/31

Чобанян А.В.

Сумський державний педагогічний університет імені А.С. Макаренка

Колиикіна А.П.

Сумський державний педагогічний університет імені А.С. Макаренка

\title{
НАУКОВО-МЕТОДИЧНІ ЗАСАДИ ВИВЧЕННЯ СОЦІАЛЬНОЇ ГОТОВНОСТІ ДО НАВЧАННЯ В ШКОЛІ ДІТЕЙ З ПОРУШЕННЯМИ ІНТЕЛЕКТУАЛЬНОГО РОЗВИТКУ
}

\begin{abstract}
Виклад матеріалу статті здійснюється в аспекті розв'язання загальної проблеми сприяння адаптащії дошкільників із порушеннями інтелектуального розвитку помірного ступеня до нових умов функціонування. У статті обтрунтовується актуальність дослідження з огляду на відсутність системних пращь із проблеми формування сочіальної готовності до навчання в школі дітей зазначеної категорії. Авторами представлено методику дослідження сформованості компонентів соиіальної готовності старших дошкільників із порушеннями інтелектуального розвитку до навчання в школі. Межами статті визначено сочіальну готовність як ключову характеристику, що зумовлює процеси успішного включення дітей із порушеннями інтелектуального розвитку помірного ступеня в освітнє середовище. Соціальна готовність до навчання у статті інтерпретується як сформованість здатності до прийняття нової соиіальної позииії - школяра, шьо обумовлена формуванням ставлення дитини до самої себе, дорослих, однолітків як суб 'єктів освітнього простору, що виявляється в здатності взаємодіяти з ними відповідно до ситуаџії. Соціальна готовність дітей досліджуваної категорії має такі компоненти: комунікативну компетентність, що виявляється в умінні орієнтуватись у різних ситуаціях спілкування, здатність ефективно взаємодіяти з оточуючими; соціальну компетентність, що характеризується як обсяг знань і рівень сформованості вмінь і навичок, щео дозволяють дитині адекватно орієнтуватися в різних ситуачіях, мати уявлення про сочіальну дійсність, себе та інших, формувати необхідні відносини з однолітками та дорослими, орієнтуючись на існуючі умови. Для виявлення особливостей сочіальної готовності дітей із порушеннями інтелектуального розвитку помірного ступеня авторами використано порівняльний принцип.
\end{abstract}

Ключові слова: комунікативна компетентність, соиіальна компетентність, стариий дошкільний вік, порушення інтелектуального розвитку помірного ступеня, критерій.

Постановка проблеми. Сучасний етап розвитку нашої держави характеризується посиленням запиту громадськості до психологічної науки в аспекті пошуку ефективних шляхів соціальної адаптації дітей з порушеннями інтелектуального розвитку відповідно до вимог суспільства. Особливого значення це питання набуває на перехідних етапах онтогенезу, найбільш складним у цьому аспекті є перехід від старшого дошкільного віку до молодшого шкільного віку, адже саме від сформованості у дитини готовності до навчання в школі залежить якість іï освіти загалом. На цьому тлі надзвичайно вразливою $є$ категорія дітей дошкільного віку із порушеннями інтелектуального розвитку помірного ступеня, оскільки їхнє основне ураження унеможливлює природний процес самостійного напрацювання моделей поведінки, що забезпечують їхнє ефективне адаптування до умов соціокультурного середовища.

У психолого-педагогічній літературі не існує спільного підходу до діагностики соціальної готовності дітей старшого дошкільного віку 3 порушеннями інтелектуального розвитку помірного ступеня (далі - ПІР ПС) до навчання в школі. Аналіз науково-методичної літератури 3 проблеми діагностики й формування соціальної готовності в дітей дошкільного віку 3 типовим розвитком (М. Айзенбарт, О. Дурманенко, В. Дьякова, О. Ковальова, Н. Семенова та ін.), у дітей $з$ особливими освітніми потребами, зокрема з порушеннями інтелекту (В. Синьов, Г. Блеч, І. Гладченко, О. Проскурняк, О. Таран, О. Хохліна, Г. Хворова та ін.), дав змогу з'ясувати важливість урахування специфічних особливостей розвитку 
дітей старшого дошкільного віку з ПІР ПС під час організації експериментальної роботи й добору методики діагностики стану сформованості соціальної готовності дітей старшого дошкільного віку з ПІР ПС до навчання в школі.

Мета статті - систематизація науково-дослідного матеріалу для визначення компонентів соціальної готовності дітей старшого дошкільного віку з порушеннями інтелектуального розвитку помірного ступеня до навчання в школі.

Виклад основного матеріалу. У структурі соціальної готовності виділяємо два важливі компоненти: комунікативну та соціальну компетентності. Критеріями комунікативної компетентності $€$ когнітивно-мотиваційний, поведінковий, тоді як соціальної компетентності - когнітивний і операційний. У межах нашого дослідження критерій визначається як засіб для судження, ознака, на підставі яких здійснюється визначення або класифікація, мірило оцінки. Вибір критеріїв відображає сутність показника обгрунтованості інформації. Тому для узагальнення одержаних результатів під час дослідно-експериментального етапу дослідження нами було використано критеріальний підхід до діагностики сформованості компонентів соціальної готовності старших дошкільників з ПІР ПС, виокремлено критерії та відповідні показники.

На думку А. Алексюка, критеріями оцінювання можуть бути характер засвоєння вже відомого знання, якість виявленого студентом уміння, логіка мислення, аргументація, послідовність і самостійність викладу, культура мовлення, ступінь оволодіння вже відомими способами діяльності, уміннями й навичками застосування засвоєних знань на практиці, оволодіння досвідом творчої діяльності, якість виконання роботи [3, с. 42].

Кожен компонент характеризується за певними критеріями. Проаналізуємо їх більш детально. Так, у складі комунікативної компетентності виділяємо:

Когнітивно-мотиваційний критерій - $\epsilon$ утворенням, розвинутим на основі знань, умінь і навичок, тобто здатності до здійснення відповідної психофізичному рівню дитини з ПІР ПС комунікативної діяльності, що виявляється в ході взаємодії з дорослими й однолітками. Ця здатність характеризує прагнення дитини до взаємодії та зумовлює готовність старшого дошкільника з ПІР ПС використовувати різні види взаємодії в новій соціальній ролі «школяра».

На думку В. Шадрікова, поняття «здатність» характеризується як «властивість функціональних систем, що реалізує окремі психічні функції, що мають індивідуальну міру вираження, що виявляється в успішності та якісній своєрідності освоєння та реалізації окремих психічних функцій». Оскільки когнітивний процес $є$ характеристикою функціонування відповідної системи, автор виокремлює розумові здатності, наприклад, здатності сприйняття, пам'яті тощо [6, с. 51-53]. У межах окресленої позиції здатність пов'язана із загальною стороною функціонування психіки, яка виявляється не в конкретній діяльності, а в загальних формах активності дитини старшого дошкільного віку з ПІР ПС.

Під комунікативною здатністю Е. Азимов, О. Щукін, О. Вовк розуміють властивості особистості, які забезпечують ефективність іiї комунікативної діяльності 3 іншими суб'єктами пізнавальної діяльності та психологічну сумісність у діяльності. До числа комунікативних здатностей належать [2]: наявність настанови на спілкування, тобто готовність індивіда до мовленнєвої активності, яка залежить від потреб і об’єктивної ситуації, рівень потреби в спілкуванні: іiї основу складають мотив і мета, тобто спонукальні фактори мовленнєвої дії, а також денотат значення мовленнєвого висловлювання (мовленнєві наміри визначають мовленнєву поведінку комунікантів).

Складність мовленнєвого дефекту при ПІР ПС визначається не тільки зовнішніми, складними морфологічними й функціональними порушеннями (мовлення, дихання, ковтання) (О. Боряк, С. Конопляста, 3. Ленів, Л. Лопатіна, Н. Манько, I. Марченко, Н. Пахомова, О. Приходько, В. Тарасун, В. Тищенко, М. Шеремет, Д. Шульженко та ін.), але й комунікативними труднощами, які призводять до ускладнень особистісної та соціальної адаптації, особливо при вступі до школи. Проте аналіз літературних джерел засвідчує той факт, що в старшому дошкільному віці в дітей із ПІР ПС з'являється інтерес до спілкування та взаємодії, що іє передумовою навчання/научіння таких дітей використанню невербальних засобів комунікації.

Відтак переходимо до характеристики поведінкового критерію у складі комунікативної компетентності.

За визначенням В. Ковальчука, поведінковий критерій - це вербальне і невербальне вираження своєї позиції в спілкуванні, віддзеркалення суб'єктивного розуміння зовнішнього середовища, вираження домінуючого емоційного ставлення, реалізація стратегії поведінки [5].

У працях О. Леонтьєва зазначено, що вербальна й невербальна системи знаків взаємопов'язані таким чином, що в межах мовленнсвої діяльності 
вони досягають свого значення й цінності тільки в умовах взаємної інтеграції та взаємної присутності [5, с. 20]. Проте дослідження зарубіжних психологів і психолінгвістів (M. Argyle, R. Birdwhistell, P. Ekman) доводять той факт, що невербальні засоби відіграють суттєву роль не тільки в спілкуванні, але й у мовленнєвоутворювальних процесах і у процесі сприймання мовлення [1, с. 207].

Поділяємо погляди I. Мартиненко щодо посилення особливої уваги використання невербальних засобів у процесі спілкування осіб із порушеннями психофізичного розвитку. Як зазначає авторка, така необхідність зумовлена тим фактом, що значна частина осіб із тяжкими порушеннями розвитку неспроможна оволодіти мовленням як засобом комунікації. Значне недорозвинення або відсутність мовлення впливає не тільки на становлення інтелекту, але й на процес соціальної адаптації цих осіб. Відповідно, в показниках поведінкового критерію визначені й невербальні засоби комунікації.

Соціальна компетентність дітей старшого дошкільного віку із ПІР ПС у межах нашого дослідження складається 3 когнітивного й операційного критеріїв.

Когнітивний критерій - включення дитини в соціальний простір, побудова відносин з іншими, починається з формування уявлень про себе.

У наукових доробках М. Гончарової-Горянскьої соціальна компетентність визначається відносно свого «Я» - у сфері індивідуального (фізичне «Я», когнітивне «Я», психосоціальне «Я») [4, с. 71]. На відміну від дітей із типовим розвитком, їх однолітки з порушеннями інтелектуального розвитку 3 раннього віку відчувають значні труднощі щодо встановлення адекватних форм взаємодії, що перешкоджає своєчасній появі усвідомленого ставлення до навколишнього світу та становленню особистісних якостей. У дітей із порушеннями інтелектуального розвитку перший прояв самосвідомості щодо виокремлення власного «Я» виникає після чотирьох років (А. Катаєва, О. Стребелєва).

Сформовані уявлення про себе впливають на становлення відносин дитини 3 людьми (дорослими й однолітками) та на розвиток усіх видів дитячої діяльності (Б. Ананьєв, Л. Божович, Л. Виготський, С. Рубінштейн), що, у свою чергу, виступає основою соціальної готовності до шкільного життя. Дослідження Л. Хайртдінової акцентують увагу на першочерговому формуванні уявлень про себе як початковому етапі соціального виховання дітей дошкільного віку з порушеннями інтелектуального розвитку.
Операційний критерій - включає набір операцій/засобів, за допомогою яких здійснюється досягнення поставленої мети, отримання результату й забезпечення ефективності діяльності, тобто операційний критерій - виконує результативну функцію.

Аналіз літературних джерел дозволяє навести деякі механізми формування таких операцій (забезпечення зворотного зв'язку індивід, індивід-група, група-група, адекватність поведінки дитини в знайомій /незнайомій ситуації адекватність застосування/використання предметів оточення): процедура візуального навчання, імітація, ідентифікація (А. Бандура, Р. Уолтерс), механізм навчання шляхом проб і помилок (Н. Міллер, Дж. Доллард), процес наслідування (Л. Виготський, Ж. Піаже, Г. Тард), організована діяльність індивіда через конкретні соціальні ролі (Т. Парсонс), цілий ряд дослідників розглядає розвиток знаково-символічної діяльності в онтогенезі (А. Валлон, Л. Виготський, В. Мухіна).

На основі вищевикладеного представлено експериментальну модель соціальної готовності до навчання дітей старшого дошкільного віку з порушеннями інтелектуального розвитку помірного ступеня в школі (рис. 1.).

Мета дослідження - виявлення рівня сформованості соціальної готовності в дітей з ПІР ПС до навчання в школі відповідно до визначених нами ii складових частин (комунікативна компетентність, соціальна компетентність).

Завдання дослідження:

1. Виявити рівень сформованості комунікативної компетентності в старших дошкільників із порушеннями інтелектуального розвитку помірного ступеня і їх однолітків із порушеннями інтелектуального розвитку легкого ступеня.

2. Виявити рівні сформованості соціальної компетентності у старших дошкільників із порушеннями інтелектуального розвитку помірного ступеня i їх однолітків із порушенням інтелектуального розвитку легкого ступеня.

Діагностичний комплекс для виявлення особливостей формування соціальної готовності до навчання дітей старшого дошкільного віку з порушеннями інтелектуального розвитку помірного ступеня у складі таких компонентів: соціальна комnетентність за когнітивним критерієм за такими показниками, як: соціальний інтелект, знання про себе та своє місце у світі, уявлення про соціальні норми, правила, розуміння соціальної дійсності, співробітництва («Методика спостереження за діяльністю дітей під час занять, виконання режим- 


\section{СОЦІАЛЬНА ГОТОВНІСТЬ ДО НАВЧАННЯ У ШКОЛІ}

\section{КОМПОНЕНТИ}

КОМУНІКАТИВНА КОМПЕТЕНТНІСТЬ

СОЦІАЛЬНА КОМПЕТЕНТНІСТЬ

\section{КРИТЕРЇ}

\begin{tabular}{|c|c|c|c|}
\hline $\begin{array}{c}\text { Когнітивно- } \\
\text { мотиваційний }\end{array}$ & Поведінковий & Когнітивний & Операційний \\
\hline
\end{tabular}

\section{ПОКАЗНИКИ}

- готовність дитини до комунікації 3 дорослими й однолітками (розуміння зверненого мовлення);

- прагнення до взаємодії; здатність використовувати види взаємодіі; позитивне ставлення та налаштування на партнера по спілкуванню.
- вибір адекватних способів спілкування, володіння комунікативною технікою (вербальними та невербальними засобами спілкування).
- знання про себе та своє місце у світі;

- уявлення про соціальні норми, правила;

- розуміння соціальної дійсності, основ співробітництва.
- адекватність поведінки дитини в знайомій ситуації/незнайомій ситуації;

- адекватність застосування/викори стання предметів оточення.

Рис. 1. Експериментальна модель соціальної готовності дітей старшого дошкільного віку з порушеннями інтелектуального розвитку помірного ступеня до навчання в школі

них моментів (у грі, вільному спілкуванні, прогулянці) діяльності); розуміння соціальної дійсності, співробітництва («Методика оцінки рівня соціального розвитку дітей» А. Закрепіної); за операційним критерієм, що визначався за такими показниками, як: адекватність поведінки дитини в знайомій/незнайомій ситуації, адекватність використання предметів оточення, забезпечення зворотного зв'язку індивід-індивід, індивід-група, група-група (Методика «Спільне сортування» Г. Бурменської); комунікативна компетентність за когнітивно-мотиваційним критерієм за такими показниками, як: практична готовність дитини до певного виду комунікації з дорослими й однолітками («Методика дослідження стану імпресивного, експресивного мовлення й засобів альтер- нативної комунікації» І. Агаєвої, Л. Лопатіної); прагнення до взаємодії, здатність використовувати види взаємодії («Методика вивчення провідної форми спілкування 3 дорослими» О. Смирнової, Х. Бедельбаєвої, А. Рузьскої); за поведінковим критерієм і такими показниками, як: вибір адекватних способів спілкування (вербальні та невербальні засоби спілкування), вибір етично-ціннісних зразків поведінки (Методика «Картинки» О. Смирнова).

Відповідно до поставленої мети й завдань було дібрано комплекс діагностичних методик, спрямованих на вивчення компонентів соціальної готовності до навчання за виділеними в експериментальній моделі показниками. Для діагностики рівня соціальної готовності до навчання у школі 
дітей старшого дошкільного віку використовувалися методики, які виявляють як суб'єктивні (внутрішні), так і об'єктивні (зовнішні) чинники формування соціальної готовності до навчання в школі.

Особливу увагу в дослідженні приділено підбору доступного матеріалу й обладнанню для виконання діагностичних завдань. Перевагу надано діагностичному інструментарію, який допомагав стимулювати виконання завдання. Одним з основних моментів у організації психолого-педагогічної діагностики дітей із порушеннями інтелекту $є$ активізація їх активності.

В основу організації дослідження було покладено індивідуальний підхід, що сприяло встановленню емоційно позитивного контакту з дитиною й позитивного ставлення дитини до завдання, диференційованому поясненню характеру завдання для отримання даних. Із метою вивчення особливостей сформованості комунікативної і соціальної компетентностей дітей старшого дошкільного віку 3 ПІР було використано й інші методи дослідження: педагогічне спостереження, бесіди з батьками й педагогами, анкетування батьків і педагогів, вивчення документації

Під час дослідження дітей старшого дошкільного віку з ПІР ПС використовувалися різноманітні засоби наочності, які стимулювали особистісну й пізнавальну активність, підтримували та спрямовували комунікативну діяльність, дозволяли підтримувати інтерес до занять, доносити діагностичний матеріал у цікавій i доступній формі: засоби наочного матеріалу, які використовувалися під час дослідження, поділялися на такі групи: натуральні, об'ємні, дидактичні іграшки, графічні наочні посібники: картинки, таблиці, схеми. натуральні наочні посібники: предмети найближчого оточення: овочі, фрукти, одяг, взуття, засоби гігієни (мило, щітка, рушник, гребінець), посуд (тарілка, чашка, ложка), меблі (стіл, стілець) тощо, які спеціально підбираються для діагностичного заняття або за ними ведеться спостереження під час режимних моментів, прогулянок.

Щоб викликати зацікавленість у дітей експериментальною роботою, було створено творчо-ігрову атмосферу: психологічні хвилинки 3 використанням знайомих іграшок, ігор тощо, спрямовані на встановлення дружніх, взаємодовірливих стосунків дітей з експериментатором, що значно полегшило проведення дослідження та сприяло отриманню достовірних результатів під час проведення експерименту. У процесі використання нових, незнайомих дітям іграшок і предметів експериментатор звертав увагу на послідовність знайомства 3 їх характерними ознаками, властивостями, якостями, формував у дітей планомірність зорово-дотикового обстеження. Експериментатор супроводжував демонстрацію наочності чітким мовленнєвим коментарем, зрозумілим для дітей відповідного віку.

Висновки. Покомпонентне вивчення соціальної готовності дітей досліджуваної категорії до навчання в школі дозволить виявити рівень iii сформованості, що надасть змогу визначити: необхідність спеціальної розробки змісту й методики психолого-педагогічного впливу, спрямованого на іï розвиток; підстави для висновку про необхідність цілеспрямованої роботи 3 формування соціальної готовності дітей зазначеної категорії до навчання в школі в цілому та їі компонентів зокрема.

\section{Список літератури:}

1. Argyle M. The Psychology of Interpersonal Behavior. Harmondsworth: Penguin Books, 1979. 322 p. Birdwhistell R.L. Introduction to Kinesics. Louisville, Ky.: University of Pennsylvania Press, 1952.115 p.

2. Азимов Э. Г. Словарь методических терминов (теория и практика преподавания языков). СанктПетербург : «Златоуст», 2009. 490 с.

3. Алексюк А. Педагогіка вищої освіти. Історія. Теорія: підручник для студентів. Київ : Либідь, $1998.560 \mathrm{c}$.

4. Гончарова-Горянська М.В. Соціальна компетентність: поняття, зміст, шляхи формування в дослідженнях зарубіжних авторів [Текст]. Рідна школа. 2004. № 7-8. С. 71-74.

5. Леонтьев А.Н. К теории развития психики ребенка : хрестоматия по детской психологии. Москва : ИПП, 1996. С. 20-27.

6. Шадриков В.Д. Способности, одарённость, талант. Развитие и диагностика способностей. / отв. ред. В.Н. Дружинин, В.Д. Шадриков. Москва : Наука, 1991. С. 51-53. 


\section{Chobanian A.V., Kolyshkina A.P. SCIENTIFIC AND METHODOLOGICAL FUNDAMENTALS OF STUDY SOCIAL READINESS FOR LEARNING IN SCHOOL OF CHILDREN WITH INTELLECTUAL DEVELOPMENTAL DISORDERS}

The material of the article is presented in the aspect of solving the general problem of promoting the adaptation of preschoolers with intellectual disabilities of a moderate degree to the new conditions of functioning. The article substantiates the relevance of the study given the lack of systematic work on the problem of forming social readiness for school children of this category. The article presents a method of studying the formation of components of social readiness of senior preschoolers with intellectual disabilities to study at school. The authors of the article identified social readiness as a key characteristic that determines the processes of successful inclusion of children with intellectual disabilities of moderate degree in the educational environment. Social readiness for learning is interpreted as the formation of the ability to accept a new social position - the student, due to the formation of the child's attitude to himself, adults, peers as subjects of educational space, manifested in the ability to interact with them according to the situation. The social readiness of children in the studied category has the following components: communicative competence, which is manifested in the ability to navigate in different communication situations, the ability to interact effectively with others; social competence, which is characterized as the amount of knowledge and level of skills that allow the child to adequately navigate in different situations, have an idea of social reality, themselves and others, to form the necessary relationships with peers and adults, focusing on existing conditions. To identify the features of social readiness of children with intellectual disabilities of moderate degree, the authors used the comparative principle.

Key words: communicative competence, social competence, senior preschool age, intellectual disability of moderate degree, criterion. 